\title{
Domestic abuse \\ in the household of God
}

\author{
Rosemaré Ann Visser \& Yolanda Dreyer ${ }^{1}$ \\ Department of Practical Theology \\ University of Pretoria
}

\begin{abstract}
The article compares the victimization that takes place in a dysfunctional abusive household and that which takes place in the household of God (Eph 2:9) where the bride of Christ (2 Cor 11:2) is abused at the hands of individuals that constitute what we know as the church system. This is often directed at the poor, individuals belonging to minority groups or those who for various reasons are unable to stand up against a system such as the Christian Church. The "analogical-familial theology" of Stephen Post is used as starting point. This "theology" involves four sequential, but nonlinear, stages: covenant, grace, empowering, and intimacy. The article broadens the spectrum of the theory beyond the family unit and to apply it to the broader family that belongs to God, the church. The aim of the article is to use these components from the analogical familial theology as framework and also as the criteria by which the experiences of those who see themselves as victims of abuse in the church are investigated.
\end{abstract}

\section{INTRODUCTION}

I was raised in a Christian family. "Christian", because the Christian church formed part of my personal identity formation within this family for as long as I can remember. Christianity for me was about relationship: my family and the Christian church. Gerkin (1997:100) describes pastoral care as being "surrounded - enfolded, 'nested', so to speak - in a living community of faith and care." This is descriptive of my experience with the church which was represented by a highly respected pastor who became a prominent part of my family life.

It was especially during the little more than one year of domestic violence in our home that the pastor and his presence became a source of

\footnotetext{
${ }^{1}$ This article is a reworked version of Rosemarié Anne Visser's MA thesis (2006), Department of Practical Theology, Faculty of Theology, University of Pretoria, with Prof Dr Yolanda Dreyer as supervisor.
} 


\section{Domestic abuse in the household of God}

comfort and strength for the family - certainly for me as a seven year old. I specifically remember him kneeling down, focusing his full attention on me, and asking me how I was. Sometimes he placed a hand on my head, looked me straight in the eyes and made conversation as if we were on the same level. These kind acts of his will remain with me forever. I cannot remember much of the contents of sermons preached, Bible studies held at our home or even lessons taught in Sunday school, which I attended from a very early age. The pastor was a soft-spoken, friendly man who, together with showing genuine interest in me, an insignificant child at the time, epitomized "pastoral care" in my earliest memories. He was the representative of the "caring community of faith" that Gerkin refers.

My father was a rehabilitated alcoholic and remained so for the wonderful first seven years of my life. Then one day an old friend of my father's visited. He brought a bottle of alcohol with him and that was the beginning of the end of the happy, tranquil family life I had known throughout my first seven years. The family and I personally, suffered the immediate and long term effects of my father's physical, verbal, emotional and financial abuse of my mother along with all the usual experiences that families have with an alcoholic as the family provider. These included a resultant deep sense of shame and consequential isolation and loneliness, feelings of anxiety and insecurity, not knowing what to expect next, and various forms of neglect among others. Although this only lasted for little over a year before my father passed away, the effects are still felt today.

The church, in our case represented mainly but not exclusively by the pastor, became our support system and for me the embodiment of safety and security as well as a place where one could take your pain and suffering. This is what I think God intended the church to be in the world.

However, later in my life the picture did not remain so ideal. As an adult I have often experienced similarities between my dysfunctional family system and my church family system. Much has been said and written on sexual abuse of members by clergy in the church in works like Victim to survivor by Nancy Werking Poling (1999). Much has also been written about power and how it affects the victims. The misuse of power is often difficult to identify because of the subtlety with which it is often perpetrated.

My personal experiences and those of individuals I have come across are astonishingly similar to my childhood experiences in an abusive household where the abuse of power in different forms traumatised our family tremendously. In this article I will compare the victimization that takes place in a dysfunctional abusive household and that which takes place in the household of God (Eph 2:9) where the bride of Christ (2 Cor 11:2) is abused 
at the hands of individuals which make up what we know as the church system. It is often the poor, individuals belonging to minority groups, or those who are unable to stand up against the very powerful systems of the Christian Church, who suffer. The result is often that people leave the church or cut all ties with anything Christian forever. Others go to another church carrying their unresolved pain and anguish (emotional baggage) with them. That, in turn, could lead to further relational problems.

The article is also an attempt to deal with the after-effects of my experiences in a dysfunctional family as a powerless seven year old child and at the same time to address what I would describe as the problems experienced today in the dysfunctional family of God in which members are sometimes victimized by others. The hurt individual is often overlooked. The article explores what can be done to prevent this abuse and to help those who are hurt. The aim is to empower the victims of abuse. I am no longer the powerless victim of my own dysfunctional family but a liberated, empowered individual who can now challenge the unequal distribution of power in the church.

In this article written case studies of persons who have been abused by the church will be analyzed and interpreted. The "analogical-familial theology" of Stephen Post as utilized by Balswick and Balswick (1999) will be taken as starting point. Balswick \& Balswick (1999:18-21) describe it as "a theology of family relationships which is based on the Old and New Testament descriptions of God in relationship". It is "a theology of family relationships which involves four sequential, but nonlinear, stages: covenant, grace, empowering, and intimacy." They also suggest that "family relationships will either be dynamic and maturing, or stagnant and dying." Firstly, this model holds covenant commitment with unconditional love as the core of any family relationship. A relationship based on unconditional love will provide an experience of security. This, in turn, will create an atmosphere of grace in which forgiveness and being forgiven is present and active. In such a gracious forgiving atmosphere family members can experience the freedom to empower one another. Intimacy will be the natural consequence of these loving, gracious and empowering relationships, which can spiral into deeper levels of commitment. Hence a dynamic process versus a stagnant and dying relationship (in which these components of covenant commitment, grace, empowerment and intimacy are non-existing) evolves.

For the purpose of this study I would like to broaden the spectrum of this theory beyond the family unit and apply it to the broader family which belongs to God, the church. I will use these components from the analogical familial theology as framework and also as criteria by means of which to 
analyze the experiences of those who see themselves as victims of abuse in the family of God, in the church. It is not the intention to judge the church. Neither is the purpose to search for "ideal" church structures in which no inequalities exist and no abuse takes place. The focus of this study is to find ways to accommodate and care for those who have experienced abuse.

\section{ANALOGICAL-FAMILIAL THEOLOGY}

Balswick \& Balswick use God's interaction with God's chosen people as a model for family relationships. In this article the model will also be applied to the church as family of God. Four important elements in God's interaction with Israel are covenant, grace, empowering, and intimacy (Balswick \& Balswick 1999:20). Family relationships will either be dynamic and maturing, or stagnant and dying. "A covenant commitment" is the logical point of departure for any family relationship, with unconditional love at its core. From the "covenant commitment"-way of relating develops an atmosphere of grace in which there is a freedom among family members to empower each other. From this empowering-type relationship opportunity and space for intimacy is created. If it develops it can lead to deeper levels of commitment. The movement between the four elements is cyclical.

Balswick \& Balswick (1999:20) describe the initial relationship between a parent and a newborn baby as a unilateral love commitment. This means that in the infant stage the covenant love only flows in one direction: From the parent to the child. The parent models and demonstrates commitment love. As the child gets older, the relationship develops into a bilateral love relationship. In order for growth to take place both persons should be involved. Growth can be blocked or retarded at any point when one person in the relationship is unable or unwilling to reciprocate covenant love, grace, empowering, or intimacy. It can therefore come to a complete standstill at any point in the cycle. Relationships are dynamic and ever changing. If a relationship does not spiral into "deeper levels of commitment, grace, empowering, and intimacy, then it will stagnate and fixate on contract rather than covenant, law rather than grace, possessive power rather than empowering, and distance rather than intimacy" (Balswick \& Balswick 1999:20)." The following points further elucidate the theory (Balswick \& Balswick 1999:21):

- The depth of bonding in familial relationships equips family members to develop empowering relationships with those in the wider human community. The family will be open to and accepting of those outside of 
the family. In this way the family contributes to and participates in humanity as a whole.

- In practice, the stages are not necessarily consequential, and can overlap.

- The elements of family relationships are derived from biblical writings on how God enters into and sustains relationships with humanity.

- The reality of human brokenness is that, although human beings have been made in the image of God, they can never enter into a covenant relationship as perfectly as God does, be gracious as God is, know and care as intimately as God does or empower without any traces of possessive power.

- Yet, in Christ Jesus, and by the Spirit of God, human beings are enabled according to the model of Christ himself and according to God's purposes.

The element of intimacy has to do with the degree of safety which is experienced in relationships. When someone feels unconditionally loved, accepted, allowed to be human and make mistakes, encouraged and guided to be who they have been created to be, there is a freedom to express, share and reveal honestly what is felt and thought. They are free of any fear of rejection, attack, failure or whatever insecurity may exist in otherwise insecure relationships.

God models true intimacy when God demonstrates an endless desire to know human beings and be known to them, to be in an intimate relationship with humankind as can be seen in the covenant relationship initiated and sustained by God. Romans 8:26-27 states that God knows and understands our deepest thoughts and feelings - even that which we cannot even utter. God knows this because the Spirit of God dwells within us. Balswick \& Balswick (1999:31) propose that family relationships that are based on the covenant and in which an atmosphere of grace and empowerment thrives, will be characterised by the following:

- they will be able to communicate and express themselves in such a way that they intimately know and are intimately known by one another;

- concerted efforts will be made to listen, understand and desire what is best for the other; 


\section{Domestic abuse in the household of God}

- differences will not only be accepted, but uniqueness will be valued and respected as a way of confirming the other person.

Balswick \& Balswick (1999:31) conclude:

This is what it means to be a servant, to empty oneself as Jesus did when he took the form of a servant. This is how one is to be submissive and loving in relationships. It is also true that to have any union or partnership or interdependence with another, one must always be willing to give up something of one's own needs and desires. When family members come to each other with this kind of attitude and perspective, they will find a common ground of joy, satisfaction, and mutual benefit.

The capacity for family members to communicate feelings freely and openly with each other is contingent upon trust and commitment. Then they are not afraid to share and be intimate with one another.

John 4:16, 18 and 19 states that God is love and fear has no place where love is. God's love is expressed perfectly and people can respond in love because God loved them first. Balswick and Balswick (1999:31) state that where there is intimacy, there is no need to be ashamed to admit failure and ask for forgiveness and reconciliation. The verbal and honest expression of affection, feelings together with seeking and granting forgiveness, will lead to mature relationships.

This theory can be applied like a golden thread running from families to individual church families to the wider church family, the community of God. The roots of the theory are in the covenant relationship. God demonstrated unconditional covenant love. The ability to love in such a way is only possible for human beings when they receive the Holy Spirit of God. This covenant love is given freely.

Eddy Gibbs in his address at the Dutch Reformed conference for about 1500 pastors on 20 June 2005 encouraged pastors to work towards churches that empower and network rather than focussing only inwardly, protecting what is theirs. A journalist report (Radio Pulpit on 22 June) summed up the conference by saying that pastors are called to serve and to take the ministry of Jesus Christ into the world. A new commitment was made that this denomination would go back to basics: being the light of God, seeking to hear the voice of God, discerning God's will for the church and the world. They wished to cooperate with the broader church in South Africa, acknowledging that God is ultimately in control. 
From a practical theological perspective the questions are: Will the gap between practice and talk be bridged? How could this be done in a postmodern world? How would the needs of people living in this world, be met? How will the church deal with the traditionalists (often legalists) who stringently oppose those in favour of change?

\section{DOMESTIC ABUSE}

\subsection{A definition}

In order to define "domestic abuse" the terms "domestic" and "abuse" need to be considered. The Funk \& Wagnalls Standard Desk Dictionary (1983:190) explains the adjective "domestic" as "1. Of or pertaining to the home or family." and "2. Given to or fond of things concerning the home or family." The Oxford Dictionary also defines the word as " 1 to do with the home or household."

"Domestic" therefore is that which has to do with the home or family. A closer look at the concept "family" is necessary. "Family", according to the Funk \& Wagnalls Dictionary edited by Melanchthon, W J et al (1983:229) is "1. Parents and their children. 2. The children as distinguished from the parents. 3. A group of persons connected by blood or marriage. 4. A succession of persons connected by blood, name, etc.; a house; clan. 5. Distinguished or ancient lineage or descent. 6. A household. 7. Any class or group of like or related things." "Abuse" is described in the Funk \& Wagnalls Standard Dictionary (1983:3) as adjective: "1. To use improperly or injuriously; misuse.

2. To hurt by treating wrongly; injure. 3. To speak in coarse or bad terms of or to; revile. - n. 1. Improper or injurious use; misuse. 2. III-treatment; injury. 3. Vicious conduct, practice, or action. 4. Abusive language; slander." An "Abuser" is the one who commits the above harmful actions.

Allender, in Lampman \& Shattuck (1999:38) elaborates on the effects of abuse on the victim: "Harm of any kind, no matter what the motive or the intent of the person inflicting it, shatters our sense of safety, predictability, and trust in the goodness of our world." It is not only the view of the world that is affected by people harming each other, but also their image of God. God is questioned and doubted. It is important to keep in mind that harm or abuse can be experienced without the perpetrator necessarily having the intention of causing pain.

"Abuse" is often wrongly limited to some form of physical violence. However, abuse is essentially about the abuser trying to control and exert power over the victim. Dutton (1992:4-7) explains how even non-violent 
behaviour can constitute abuse: "Non-violent behaviours may take on the same property as violent behaviours when their function is to control a victim". She continues: "It is important to recognize that the abuser typically continues to maintain some level of control even when not actively engaging in abusive behaviour" (Dutton 1992:18). Ganley (1981) identifies four forms of abuse: physical, sexual, psychological, and abuse towards property and pets. Pence \& Paymar's Power and Control Wheel (in Dutton 1992:18) indicates different methods of using power and control. In addition to physical and sexual violence there are coercion and threats, economic abuse, intimidation, emotional abuse, using male privilege, using children, minimizing, denying, blaming and isolation.

\subsection{Profile of an abuser}

With some knowledge of the profile of abusive personalities churches could follow a more pro-active and "hands-on" approach to the prevention of abuse. Are there recognizable qualities inherent in those who seek power and control over others? Some such qualities include (Edleson \& Tolman 1992:37-46):

\section{- Behavioural deficits}

Abusers tend to exhibit an assertiveness deficiency. Maiuro et al (1986) find that "batterers" can generally defend their rights and territory effectively, but have difficulty expressing their desires in a socially appropriate manner. This goes along with possible greater feelings of "loss of personal control and more vulnerability to rejection when attempting to express their needs". They have a greater need for power than men without relationship problems. According to Edleson \& Tolman (1992:3746) this suggests that abusive men may view intimate relationships with women not only as dangerous but as uncontrollable. This may lead to extreme anxiety and anger. Therefore, they have high power needs but low verbal assertion. This does not allow them to satisfy their power needs verbally, which leads to violent (and I believe any other form of abusive) behaviour.

\section{- Depression}

Empirical evidence suggests that depression is a factor in men who batter. The depression is often related to the consequences of their abusive behaviour, but it could also possibly be of a longer standing sort. 


\section{- Hostility}

Men who are physically abusive are more likely to feel angry in conflict or anxiety situations than men who choose not to act violently. Abusive men have difficulty expressing and labelling emotions other than anger. An over labelling of any type of negative affectivity as anger is likely. Selfgenerated anger is often used as a rationalization for the abusive behaviour.

\section{- Alcohol and drug abuse}

Chronic alcohol or drug abuse is a good predictor of abusive behaviour.

\section{- Sex roles and attitudes}

Abusive men experience themselves as low in masculinity and low in the positive traits stereotypically associated with both sexes. Abuse bolsters their masculine self-image. Negative attitudes towards women that are promoted culturally, contribute to women abuse. Hostility and negativity to women are expressed in subtle and not so subtle ways.

\section{- Psychopathology}

All abusers do not have psychological problems. However, a large number of those receiving treatment have been diagnosed with psychological disorders. This is especially the case among substance abusers. Hastings \& Hamberger (in Edleson \& Tolman 1992:37-46) identify three major subgroup profiles:

- Associated with the borderline personality disorder, individuals who are a-social, withdrawn, moody, and hypersensitive to interpersonal slights. These individuals are viewed by others as volatile and reactionary. They can be quite calm one minute and extremely angry the next. High levels of anxiety, depression, and alcohol problems are typical of this group.

- Associated with narcissistic and anti-social personality disorders, are persons who are self-centred and use others to meet their needs and only reciprocate when it is to their own advantage. They insist that their perceptions, values and rules be accepted by others. Hesitation to respond to their self-centred demands violates their sense of entitlement to be treated according to their own standards, and they respond with threats and aggression. 
- The last profile is that of rigid, tense individuals who are passive and ingratiating and are typical of dependent/compulsive personality disorder. They lack self-esteem and have a strong need for one or more significant others. Rebellious, hostile feelings can result from a failure to meet these needs. The have low anger levels and moderate depression.

\section{DOMESTIC ABUSE AND ABUSE IN THE CHURCH}

As the physically "weaker" sex, women have always had to devise ways to avoid, prevent or get away from being abused physically by men. Many a divorce has physical abuse as its root cause. More difficult to always pinpoint because of the absence of marks and other forms of physical evidence, is emotional or psychological abuse. Power and control are the main goals of the perpetrator of abuse. Patriarchal societies and structures, which include the church, tend to violate the humanity of women. According to Elizabeth Stanco (1985:4) women are often blamed by society for men's "indiscretions", which result from their own "unrespectable" behaviour. Stanco (1985:20) identifies different forms of abuse. They are the following:

When an individual has been exposed to incest, she sees being abused sexually as part of being human or a woman. Stanco (1985:20) explains as follows how women are "conditioned" for their role in society:

By age 5 or so, she is also likely to have acquired many of the ingredients which make up the ideal female temperament of a female in today's society which she is expected to exhibit adeptly to others ... she is helpful, nurturing, supportive, loving ...: as part of the pink world, incestuous assaulted children learn that their female role also entails sexual availability to men.

The abuse does not stop with daddy, but continues as an adult years later when she accepts her role of being used sexually for a man's pleasure. This often means living with what Stanco (1985:20) describes as "terror", which is the result of a constant state of anxiety, coupled with the unpredictability of the next sexual intrusion and the form it would take. Stanco (1985:22) mentions some of what the victims of these forms of abuse share: "confusion, shame, humiliation, powerlessness." This becomes the norm for some women.

In the church, especially in heavily patriarchal churches where pastors or leaders humiliate women, such abusive behaviours are often accepted as normal. People in the case studies below are probably the braver ones who 
have identified this behaviour as abusive, in contrast to the many who simply accept it as the norm.

This acceptance can be a form of denial. Furthermore denial can cause the victim to remain in the situation, while she denies the reality of what is experienced every day. Victims even come to a point of accepting responsibility for the abuse. The perpetrator affirms this by taking no responsibility for the difficulty or disagreement. Silence is a typical result. The terror, shame, humiliation, powerlessness in the face of whole societies that look the other way, often cause children who are victims of incest to block out the memories. I believe this is the case in the church as well. Being labelled as "liberal", "trouble-maker", "disrespectful", causes people to defer to unequal and abusive treatment in patriarchal churches out of fear for the shame, humiliation and powerlessness that are all effects of abuse. Women are seen as "proper women" when they submit to the men in their contexts. Asking questions or wanting to be treated as an equal, assures a woman of the label "rebel". For many women the best alternative to this abusive treatment is silence or leaving.

Silence and withdrawal enable the abuse of others to continue uninterrupted, or it is hidden from higher bodies of the church. The abuse remains undiscovered, just like incest is kept secret (Stanco 1985:25). It does however continue to hurt the victims and their future relationships and families. Similarly, the individual that leaves the church silently, trying to suppress or block out the hurt (often referred to as "forgiving and forgetting" because that is the Christian thing to do), will go on to the next church with unresolved issues, causing further difficulty in these new relationships.

Edleson \& Tolman (1992:7) report that the effects of abuse take the form of both increased physical illness and emotional problems among women and child victims. Of these two, the emotional problems, such as suicide tendencies, guilt feelings and depression, are the more devastating. According to Edleson \& Tolman (1992:8) a positive correlation was found between verbal abuse (psychological maltreatment) and depression by Straus, Sweet, and Vissing (1989). Children observing abuse were found to experience "lower levels of social competency, lower academic achievement, and a variety of emotional problems including depression, suicidal behaviour, and insomnia.

Herman (1992:33) points out that, according to the Comprehensive Textbook of Psychiatry, the common denominator of psychological trauma is a feeling of "intense fear, helplessness, loss of control, and threat of annihilation." Similarly, in the case of the church, there is the fear to reconnect with another church or to be exposed to similar treatment in the next 
church. Herman (1992:34) puts it as follows: "Traumatic reactions occur when action is of no avail."

\section{PASTORAL CARE}

\subsection{Where did it go wrong?}

When things go wrong, such as, for example when the church which is supposed to be a healing, caring, nurturing space inhabited by people who follow in Jesus' footsteps, hurts people by wielding power over them en being abusive towards them, then Practical Theology has a task. Willows and Swinton (2000:29) put it as follows:

The special task of Practical Theology is to start with the concrete, historical, immediate reality critically evaluating and enabling the practical life of the Church in all its many forms, drawing on the findings of fundamental, historical and systematic theology. At the same time, however, Practical Theology will be needed by these others as they too wrestle with the task of enabling the Church to stand faithfully in today's world.

Ogletree (in Willows and Swinton 2000:28) agrees that "( $t$ )heology is practical in the sense that it concerns, in all of its expressions, the most basic issues of human existence." Pastoral care is therefore about "human existence".

"Human existence" should be central in Practical Theology and in the church. However, Alsdurf \& Alsdurf (in Horton \& Williams 1988:165-169) refer to the investigation of Stacey \& Shupe which indicate that clergy response to the problem of wife abuse has been inadequate. Alsdurf \& Alsdurf, in their own study on clergy response to women abuse, found it disturbing that only $10 \%$ of the 5700 questionnaires sent out were returned. This says something about the priority and significance given to the issue of women abuse by clergy. The findings of Alsdurf \& Alsdurf (in Horton \& Williams 1988:167-169) are the following:

- "Pastors did indeed seem to hold patriarchally informed attitudes toward women."

- "Their comments revealed them to be concerned about battered women and yet torn by the theological perspectives that appear to conflict with this concern." 
- They further found that $92 \%$ would never advise the victim to leave the abuser.

- On average a third held the victim wholly or partially responsible for the abuse experienced, by "an unwillingness to be submissive", by "overestimating the responsibility of the abuser for the violence" and by advising the wife to stay in the situation and pray and trust God to deal with the abuser.

- Pastors were not trained adequately to deal with abuse.

The above studies were conducted regarding wife abuse, but I believe that they reveal attitudes towards women which shed some light on pastoral care in general. What is important to note from these findings is that:

- theological perspectives determine attitudes of pastoral caregivers;

- conflict exists between moral and theological stances;

- institution is valued above the human individual's pain (the marriage institution or the church institution);

- the training of competent carers is essential.

The analogical-familial theology, building upon the suggestions for family life as suggested by Balswick \& Balswick, can provide a good model for pastoral care. Shepherding is maybe the most appropriate example given by Jesus Himself. Jesus' shepherding follows in the footsteps of God, the father, who modelled these elements from the earliest creation days.

\subsection{A pastoral care model}

Covenant Love is central to pastoral care. In analogical-familial theology "covenant" forms the basis and starting point of pastoral care. An awareness of the extent of the problem of abuse is necessary. It is not possible to love unconditionally if we have views that only allow us to care under certain circumstances and conditions or if we hold views that some people are not equal to others. I further suggest that covenant love has an active element to it. Pastors should actively try to get to know and understand the experiences of all in their care. This should and will, according to Balswick \& Balswick, spiral into deeper levels of intimacy. Intimacy, which is an element of their theory, has to do with a desire to know and to be known. 
I would like to see this element broadened to include honest attempts to really understand the other, even those labelled as "difficult". In the context of covenant love, the active attempt to know and understand should start with a careful scrutiny and examination of Scripture. Salter (1990:193 - my italics) describes the shepherd's task as follows: "He knows the sheep individually and is known by the sheep." Pastors should always endeavour to learn more about all people entrusted to them, those who abuse and those who are abused. Edleson \& Tolman (1992) expand on why such knowledge is necessary: "While battering itself is the focus of intervention, many individual characteristics of men may affect the course of intervention. Identification of characteristics that discriminate "batterers" from non- "batterers" may increase the accuracy of prediction of recidivism and improve understanding of the causes of maintaining factors of woman abuse."

The focus should, however, not be on knowledge only, but on creating a safe space in which people can feel free to accept themselves. This is to the glory of God. Human beings were created by God. They should honour that, which would then lead to a healthy self-acceptance. Creating awareness of abuse within the church can empower the whole body to be pro-active and hands-on in the prevention of abuse. This may include creating opportunities in which people can safely and honestly explore, share and learn more about abuse in their own families. The abuser can and should also feel safe enough in the church family to seek help and talk openly about the reasons for the need for power and control over others. In an atmosphere of unconditional love those who hurt in their families will not be judged, but will have the freedom to seek the support of the family of faith.

Pastoral care faces the challenge to firstly create an atmosphere where people feel safe enough to tell their stories. About the process of dealing with trauma Herman (1992:162) emphasises the importance of safety: "From control of the body, the focus on safety progresses to control of the environment. The acutely traumatized person needs a safe refuge. Finding and securing that refuge is the immediate task of crisis intervention." I believe that the same is true for any victim of abuse of whatever sort. This is also true for all people, since all are in need of safety. Where grace (forgiving and being forgiven) is normative in a community, people are not afraid to tell their stories. They will know that they will not be further victimized because they have failed, or if they tell a story of being abused in the context of the faith community. We've seen that the actions of the abuser aim to take away control or power from the victim. Therefore it is of the utmost importance that pastoral care has as its primary focus, creating a space where power and 
control can be regained by the person who has been victimized. This is the element of empowerment in the familial-theological theory.

Salter (1990:193) says the following about the role of the pastor: "Skilled shepherds attempt to do all the right things so that the sheep under their care will reach their maximum potential as sheep, that they will become good wool-producing, meat-providing, or reproducing sheep." For those who perpetrate abuse (sometimes unintentionally) pastoral care can facilitate practical help such as clinical help or life-skills training, for example assertiveness training, since abusers often cannot express their feelings and needs in socially appropriate ways. Often their behaviour has its roots in having felt powerless and helpless at some earlier stage in their life history. For the depression that is a factor for abusive persons Edleson \& Tolman (1992:38) suggest that "a supportive intervention environment may offer him hope and support in managing the depressed affect." They stress that the intervention should, however, still focus should on the abusive behaviour and its consequences. Persons who may be suicidal or homicidal should be supported to enter into programs or services because this may interfere with the intervention process.

The overall most important aspect of empowerment is creating an atmosphere in which people can feel free to develop and grow, to discover their gifts and calling by means of trial and error, not fearing to fail some perfectionist leader (see case study 4 in Annexure). This can take place in a community where intimacy means open discussion about one's personal spirituality and discerning God's will. Preaching can be adapted to include the realities of abuse (if the preacher is not the abuser!) in which beliefs, especially in cultures where it is acceptable if one is angered, are challenged. With this I am suggesting that pastoral care should maybe be relevant to every day life. The realities of abuse and problematic relationships and difficulties should form part of our contacts, whether at the church or at people's homes. This may lead to a closing of the gap between theology (church life) and everyday life. Practical Theology aims to bridge this gap.

The people in church and clergy should learn more about the relationships between certain behaviours and abuse, for example substance abuse and the abuse of power. This suggestion implies empowerment by knowledge. Pastoral caregivers should be willing to learn what is necessary in order to be effective in their ministry.

Some of the stories in the Annexure may seem like trivial everyday experiences to some readers. Yet, these experiences were traumatic for the victims, and therefore suitable for this study. Furthermore, the church or representatives (often in the form of leadership) were seen by people who 


\section{Domestic abuse in the household of God}

experience themselves as victims, to be the perpetrators of such abuse. In order to minimize the traumatic experiences the abused often acted in a way which contributed to their powerlessness and hopelessness. Such behaviours go hand in hand with traumatization, whether physically, psychologically or otherwise. Minimization is listed by Dutton (1992:21) under the category "emotional abuse". In this academic endeavour one would therefore not in any way want to minimize these stories. What is important is that the experiences of the victims were hurtful and traumatic in all the case studies presented above.

Abuse causes symptoms which can, in its severest form, lead to Post Traumatic Stress Disorder (PTSD). Experiences of abuse or trauma include feelings of being overwhelmed. Herman (1997:33) describes the traumatic experience as follows: "Traumatic events overwhelm the ordinary systems of care that give people a sense of control, connection, and meaning." It is about feeling robbed of control. It is also about disconnection (in this case from other church members, the institution of which the victim was a part, sometimes for many years, from the self and one's beliefs, and even from God). There is also a sense of a loss of meaning: having lost being a part of, and having a purpose in, or making a difference in the context of the body of Christ).

The following are some of the actions identified in the case studies, all of which are listed in Dutton's (1992:21) table of emotional abuse:

- unilaterally defined male/female roles;

- major decisions without equal participation;

- withholding information or access to family resources;

- attempts at making the victim feel guilty;

- insults or "put downs";

- instilling fear by looks, gestures, actions;

- treating the victim like a servant (or lesser being);

- minimizing;

- attempts to manipulate the victim to drop the charges against the abuser.

The above is listed by Dutton (1992:21) specifically in the context of battered woman. It is therefore about male abuse of a female partner. I have used it here to stress the similarities between what happens in an abusive relationship between a man and woman in domestic abuse and what happens in the "domestic" relationships in the church. I believe that abuse as understood here, is not limited to males abusing females. The opposite is also true. What is important is the ways and means used to hurt one another. The case studies have to do with people's experiences in the church system. We 
see that the behaviours listed above are used in the church to inflict hurt and to gain power and control over others.

Carefully scrutinizing each one of these studies, I have found that in all cases Covenant Love was absent in the experiences of the victims. In these stories we cannot conclude that anyone of the individuals felt unconditionally loved. Grace was equally absent. In all cases apologies were offered by the storytellers (victims) even if they felt that they were not at fault. In all cases they felt that they had to unfairly accept all responsibility for what went wrong in the relationship. In Case Study 4, one of the pastors offered an apology, accepting his role in the pain that was experienced by the subject, only to withdraw after a few days because, after some discussions with other people, he felt that his behaviour was justified.

Empowerment was clearly absent in the experiences of victims in all the case studies. Women felt that they were treated as less than males. Victims felt that their gifts were not acknowledged in the church. Intimacy was absent in all cases because subjects experienced that major decisions which would affect them directly, were taken without having been consulted. It is a sure sign of abuse when people feel that since there is no intimacy, the only way to get away from the abuse, is to leave. Where there is intimacy people will feel free to share how they feel and what their expectations are without a threat to be humiliated or hurt in any way.

\section{Works consulted}

Balswick, J O \& Balswick, J K 1999. The family: A Christian perspective on the contemporary home. Grand Rapids, MI: Baker Books.

Dutton, M A 1992. Empowering and healing the battered woman: A model for assessment and intervention. New York: Springer.

Eddleson, J L \& Tolman, R M 1992. Intervention for men who batter: An ecological approach. Newbury Park, CA: Sage.

Gerkin, C V 1997. An introduction to Pastoral Care. Nashville, TN: Abingdon.

Hastings, B M 1999. Cognitive, contextual, and personality factors in wife abuse. Hastings-on-Hudson, NY: Hastings Center, Institute of Society, Ethics and the Life Sciences.

Horton, A L \& Williamson, J A (eds) 1988. Abuse and religion: When praying isn't enough. Lanham, MD: Lexington Books.

Lampman, L B \& Shattuck, M D (eds) 1999. God and the victim. Cambridge: Eerdmans.

Melanchthon, W J, Lane, E C \& Zenos, A C (eds) [1936] 1983. Funk and Wagnalls new "standard" Bible dictionary. Designed as a comprehensive help to the study of the Scriptures, their languages, literary problems, manners and customs, and their religious teachings. $3^{\text {rd }}$ Revised edition. New York: Funk and Wagnalls. 
Poling, N W (ed) 1999. Victim to survivor: Women recovering from clergy sexual abuse. Cleveland, $\mathrm{OH}$ : United Church Press.

Salter, D 1990. What really matters in ministry: Profiling pastoral success in flourishing churches. Grand Rapids, MI: Baker Book House.

Stanco, E A 1985. Intimate intrusions: Women's experience of male violence. London: Unwin Hyman.

Willows, D \& Swinton, J (eds) 2000. Spiritual dimensions of pastoral care: Practical Theology in a multidisciplinary context. London: Jessica Kingsley. 


\section{ANNEXURE: CASE STUDIES}

\section{CASE STUDY 1}

The following story is told by a 43 year old white male who left a church in Pretoria. At the time of writing this story he still experienced tremendous grief about his loss of dignity, his church and dear Christian friends. His family was very popular among the church members (about 600) which made the process even more difficult. They are still in friendship relationships with many of the members. The story in his own words:

I was very happy when we first joined this church in Pretoria in 2002 and we quickly made lots of friends. We were generally well accepted by the members and adherents of the church. We, and especially my wife, are well known and respected nationally in our church denomination circles.

As time went by, both my wife and I were identified as leaders. We were approached to lead the young adults in a Bible study group, and since teaching is really my wife's gift, she did most of the leading. One of the bible study members was a new student of theology at a reformed institution, where he was taught that it is not biblical for women to teach any group which included men. This teaching started to spread and another young lady called to let us know that she would not attend the Bible Study anymore because of her newfound conviction that women should not teach men in the same group.

I later asked the senior pastor regarding this policy as it was not mentioned when we were asked to join the group as a couple or at the membership classes of the church which we attended for six weeks prior to becoming members of the church in 2002. He said that my wife could continue teaching the group for now as long as I was also present at the Bible study groups to oversee her teaching. He further said that he would do a series on the issue. He stated that it is biblical that woman should not teach men and that, as long as he is the pastor of this church, it will remain a principle. He repeated this statement later in a Sunday morning sermon.

My wife was invited by the leadership of the church to become the leader of the educational department. While in the process of arranging meetings with the leaders of the different departments of this ministry, which included adult Bible study groups run on a Sunday morning at nine o'clock, she was informed by some of these leaders that the adult groups were taken away from her, again based on the above "principle" about women in leadership positions.

The adult groups will now be headed by men. Adult men could not report to a woman. She was never informed before of the reason for taking it away from her or of the mere fact that they are taking it away, but it was clear that the senior groups consisted of adult men and women. It was confirmed later when we enquired that this was indeed the reason. I felt uneasy about the issue and in the way it was done, and studied the Constitution of our church to see if it makes any mention about the role of women in the church, but found none. It only states that "all people are equal before God", and that "all members have the freedom before God to interpret the Scriptures in their own way". When I challenged the pastors on the issue, they were adamant that it is a principle in the Bible and is not open to interpretation. The senior pastor stated that women will always be under the leadership of the men at "his" church. 
The church Constitution was later also amended to include more elders, to ensure that all ministries are overseen by the elders to ensure male authority. It was clear that the church was going towards a Presbyterian system.

My wife received numerous calls criticizing her for the way she led the ministry and was also called into a meeting with the two pastors of the church, on all occasions about trivial issues. I once compared what I observed as very similar to what happens in abusive husband/wife relationships. My wife was a part of the church; known, loved and admired by all until she accepted the position of leadership. The relationship clearly changed overnight from one in which she was "courted and treated very well" to one in which she was continuously criticized, humiliated and emotionally abused in my view. She often apologized but never received any apologies or signs of shared responsibility from their side. I was disappointed and hurt so see how this hurt and affected my wife. I live with her and know her heart and commitment and it hurt me to see this behaviour towards her. I wanted to challenge the Pastors about the issue, but after talking to my wife, we decided to let it go, and that she will just try to ignore the constant criticism and carry on with her job. I need to say that no one else was aware of the things that she was so often accused of. It was only two pastors communicating through an elder that "the Leadership was unhappy ....". She was a popular and loved leader in her different ministries. After she left, those that served under her were deeply hurt. One lady specifically said that it felt as if a leg was amputated. The abuse of my wife also affected and touched others.

In the mean time, I was elected as a Deacon and started attending the Executive meetings. I was shocked at the way in which the senior pastor spoke to the other pastor when there was a misunderstanding about the preaching roster. He attacked him verbally in the meeting, in a way that I will not talk to my children. The other pastor was very apologetic, but the senior pastor made known the unacceptability of the "slip up".

My wife was again in trouble when she organized a fun event at the church and sold tickets to cover the costs. I took it upon myself to help organize the event, and spoke to the senior pastor about our intentions before doing any planning. He was elated about the idea and gave us his blessing. I started making posters to advertise the event and also used the overheads during church meetings for this purpose, clearly indicating that we would charge money. My wife was reprimanded by one of the elders in his private capacity two days before the event that it is not biblical to sell anything at church and quoted Bible verses to make his point. My wife responded in a loving way to the complaining elder, making clear what her intentions were, after which he then changed his mind and said that he will gladly support the event. This is the way I believe we can solve our differences in the church. After the event, however, my wife was again told by another elder at an official meeting that the "Leadership" was unhappy and that it is indeed against church policy to sell things at church. He also stated that the senior pastor said that he was never informed of the event and not aware that we were going to charge money to play the games. I was again very upset and shocked that he will make such a statement, since I personally informed him of our intentions. We advertised extensively for three months before the event took place (making posters, power point presentations, promotional skits [performances] in the church), never hiding the fact that we would charge money. We could not understand why anyone representing the "Leadership" 
did not approach us during these three months before the event. We tried to get copies of the Church Policies regarding these issues, but found none that was in any printed format. The "Leadership" stated later that it is an "unwritten principle", but that they are in the process of formulating a special "Rule Book" for all leaders.

During this time, I also learned about an issue regarding a woman who was involved in the music ministry. After being involved in this ministry for nine years, she was left out without any acceptable reason. She was told that the teams were full and she would not be needed anymore, but others informed me that they did not "like her voice". I approached the assistant pastor who happened to be the leader of this ministry and told him that this lady was very hurt and upset about the fact that she was left out. He later came back to me and told me that she was informed of the reasons for her being left out and that she accepted it. I was not convinced and raised the issue at one of the executive meetings. The response from the senior pastor was again shocking and he challenged the assistant pastor regarding the issue. It became clear to me at this meeting that other women were also left out during the process of making up the teams and that they were all very hurt. The result was that the assistant pastor was ordered to approach each of these women and to apologize and to reinstate them. I thought that it was the end of that issue, but were phoned days later by the assistant pastor, and he tried to investigate the issue by challenging my intentions for going into the matter. I ensured him that I felt bad for the way in which the selections were done and that the specific woman was very hurt in the process. This ministry was her life and they took it away from her. He later informed me that he had long meetings and discussions with both the senior pastor and other leaders of this ministry, and that they believe that they did not do anything wrong that requires any apologies from their side. The woman involved later told me that the assistant pastor made her feel like he was suspecting her of having an affair with me, in the way that he questioned her regarding the fact that I challenged them about the issue. I felt very sad that they could not just accept that they have hurt another person and that they only had to do what was decided at the executive meeting, but instead they preferred to "prove" their righteousness by making a court case out of the whole issue.

Since then, I felt that I could not identify with the way in which the "Leadership" went about their business at the church and told my wife that I could no longer be associated with the Leadership of the church. I did not see the servant leadership that was promoted in the Bible. I did not see how they could treat the women as being "less than men" and still preach that "all is equal before God". I realize now that the "Leadership" is men that are placed in a position of power and will use any means to keep the control of that power. They seem to be threatened by women who have the potential of challenging their positions, although most women are only too happy to serve under a "loving husband", or pastor.

When I informed the senior pastor that we have decided to leave the church, he immediately accused me of having a history of not being able to stay at one church. This was not true, we have never left any church because of unhappiness before and belonged to this denomination for more than twenty years. He also stated that us leaving will damage his image. I was again very shocked at his response and that just summed up the whole chapter of our life at this church.

I have been a Christian for more than twenty years and this was the ninth church in our denomination that we attended. My job in a construction company 
takes me to wherever the work is. Our moving - and thus often moving church as well - resulted in his interpretation of "us not being able to stay at one church". This was the first time that I felt it necessary to have to leave the church. The problems started when we were put in a position to challenge and question some things in the church. I believe we were labelled among the two pastors as being "trouble makers", whereas we were indeed "pouring out our lives for the Lord" and coming up for those that did not have a voice to protect themselves. In the process, I was disappointed, hurt, saddened and hardened to the fact that not all Christians are "laying down their lives for their friends". I am sad to say that, for me this church is comparable to a "business" where the leadership is indeed rather an executive sitting at the top, making sure that their laws are abided by - laws that they often break themselves, with some excuse or other which makes it acceptable for them to do so, instead of serving the flock. I am sad that I lost real loving friends and brothers and sisters in the Lord due to men who are hide behind the same laws that our Lord Jesus Christ came to nullify. I have been deeply traumatized by my experience in this church.

\section{CASE STUDY 2}

The following is a story of a 48 year old coloured woman. Her husband, pastor of a Johannesburg church in a black community, committed adultery. She tells a story of experienced neglect and rejection by her church. In her own words:

My husband is a pastor and youth leader of the church we belong to. He also had a daytime job outside of the church. My husband had an extramarital affair with a young woman in her twenties in the church. I trusted and respected this woman prior to discovering the affair. She was like a daughter in my home. I had my son, aged six at the time, and could not always attend all the meetings with them. My husband often came home late. I felt guilty that I wasn't part of his ministry. I never questioned him. This woman often slept at my home. One day one of my daughters told her sister that she saw something inappropriate happening between my husband and this woman in our home. My daughters told me about it. I did not know how to confront him. What if my daughters had made a mistake? He was their stepfather, which would just complicate matters. Our relationship became more and more strained, with my husband often "working late" and withholding information from me. He always ministered with this woman by his side. I felt that she took my place next to him in his ministry and his life.

I decided to make an appointment with the senior pastor of the church to discuss the matter with him. He said that he had noticed that "something strange" was going on between my husband and this woman. He then asked me why I did not fulfil my role as my husband's (pastor's) wife. I challenged him about my husband's strange behaviour. He made no effort to talk to my husband or to get involved in our affairs. He said he would pray for me. This made me extremely angry. I felt that this person, the senior priest, should, in his role as senior, but also as shepherd of the flock, at least try to bring us together to discuss the matter. Questions like "Why are you here, man of God? My family is breaking up" entered my mind. Somehow I felt it had to do with the fact that I'm a woman and that, being in a black society (culture) it is somehow okay and even expected/common for men to abuse/use women and 
have other relationships. I felt I had nowhere else to turn if the representative man of God did not care about my hurts, concerns and the possible break-up of my family. I was my husband's third wife and surely this should ring a bell that maybe this man has problems in the area of relationships. I remained a member of the church lonely, hurt, I stopped attending services. After about a month the senior priest and his wife came to see us at home. He was a different man and played a different role in the presence of his wife. His wife mentioned that she was aware of the unhealthy close relationship between my husband and the young woman, but found it difficult to approach the young woman about the issue, especially because I never mentioned anything about having a problem. She got upset and said that it would be wrong to mention names, but that others were also mentioning and noticing the relationship between my husband and the other woman. The senior priest said that he discussed the issue with one of the other priests in the church, who informed him that he had already addressed the matter with my husband. This was the first I heard about this. I felt hurt that no one discussed the matter with me at any time. I was discussed and my life issues addressed, but everyone was silent to me - almost waiting for me to come to them. Everyone seemed to be aware of what was going on and I was the last one to find out. I felt that I was excluded often because I was coloured and this was a black community church.

My husband just sat there while the priest, his wife and I discussed his relationship with this young woman, but did not open his mouth. The priest told me to forgive and forget and to come back to church. He did not consider or understand the rejection I felt, the failure I felt. Forgiveness for me comes when someone claims or accepts their responsibility and asks for forgiveness. This never happened in my marriage. The priest told my husband to ask forgiveness, after which he mumbled "forgive me". I agreed to go back to church. I felt angry inside that he never admitted or showed regret for the wrong he had done. Where is the presence of God in this man? He is the man of God. I went back to church, still angry, boiling inside. I did this to please them, but I had so many questions without answers. I even questioned the Lord. "Lord, you gave some all this knowledge of your book, the Bible, but I don't see it in practice. Don't they understand the message?" Back in church my presence made my husband very uncomfortable. It was as if I saw him naked. After the service my husband asked to say something to the congregation. He addressed the church, stating that he would like everyone to know that his wife does not come to church because she suspects him of having a relationship with ..., mentioning the name of the young woman. He denied having any such relationships. The previous night when the priest and his wife visited our home and where the matter was discussed at length he did not deny the relationship. This portrayed me as the problem, in spite of everything that was said at our home, including the acknowledgement of many of their awareness of the "unhealthy" relationship between my husband and this woman. I was humiliated. Everyone was present, including the children, when he did this.

I stood up and apologized that my husband mentioned our family problems in the church service. The aunt of the young woman got up and said yes, people are aware of the relationship and that the aunt tried to speak to her before, but that she denied everything. The aunt continued that the church should pray for me not to entertain the demon of suspicion. (Did she also entertain the same demon when she 
questioned the woman regarding her own suspicions?) She prayed a prayer which was more like a sermon directed to me. I never returned to this church.

Our marriage relationship just got worse. He stayed out late more and more and eventually abused me physically and withheld resources from me as well. Eventually he moved out, and went to live with another girlfriend - all this while he is still pastor of the church.

Another surprise waited for me. He came home recently, sharing the news that he has AIDS. He also asked for a room to stay in. I was devastated and went for numerous HIV tests. He now does not have a vehicle and expects me to provide for him and care for him. What hurts most is my son's regular plea: "Mommy, just give him another chance!" What does a child understand of the pain and devastation I suffered under this "man of God", my son's father?

I do trust, however, that God used the ways in which the church failed me to strengthen me. God took away the load, the hatred. I was left only with God, who took away my anger towards this church family that failed me, abused, humiliated and hurt me. God cared for us when he, the priest of a church did not care.

\section{CASE STUDY 3}

The following story was written by a 50 year old lady about her church in the Northern Cape. In her own words:

In 1993 our church had a vacancy for a new minister. A minister from Pretoria was invited to preach to the congregation. His English was very poor. The governing body of the church were still considering who to call when they received a telephone call from the above minister. He informed the church that he had already resigned as a Dutch Reformed minister. It was then decided to call him to fill the vacant position.

He had only just settled down in the city when he started finding fault with the session clerk and his family. They were the first to leave the church with bad feelings.

The new minister then put a stop to the Women's fellowship meetings saying that everybody had to do everything together. Next he stopped Sunday school which resulted in many people leaving the church in search of a church where the children could attend Sunday school.

However, a family Bible hour was started before church on Sundays, which was led by a young man who was excellent. It wasn't long though before the minister verbally attacked the young man in front of everybody at the Bible hour because he didn't agree with him. After many similar attacks on the young man, the details of which I do not have, the young man also left the church.

During my time there this minister verbally abused my brother several times. My brother was a Deacon and the minister turned up at his house one day and started shouting at him and told him that he wasn't a Christian and was not worthy of being a Deacon. Three times he verbally abused him in this way. The minister denied having done this when the Elders took him to task. My brother and the minister eventually sorted out there differences - my brother always having to apologize of course and take all the blame.

My husband and I left the church not because of any personal experiences with the minister but because we did not like his authoritarian ways. 
He did not tolerate anyone disagreeing with him and slowly but surely got rid of all the elders and deacons, who were "always in the wrong".

After several incidents my brother also left the church.

The minister went to one of the women in the church who was going through a divorce and told her that she was going to hell.

He now runs the church on his own, doing as he sees fit. He does not have an elder or deacon. He sees himself as the only one who is right and the only one who knows the truth.

When Prof Johan Heyns was murdered, he told everyone that it was God's judgement on him - he had received his just deserts.

He was always judging people.

My brother finally decided to leave the church after he was reprimanded three times during a Bible Study for turning a page of the Bible during a prayer meeting. This was done in the presence of everyone attending the Bible Study.

Although he had put a stop to the Women's fellowship, he is now living on the money that this fellowship had raised to start an old age home."

\section{CASE STUDY 4}

The following story is told by a 51 year old woman. In her own words:

As a child I went through a very tough time. I was insecure, due to low self-esteem. I was very sick as a child. At the age of $9 \mathrm{I}$ had Sydenham's chorea, which attacked my nervous system and at the age of $10 \mathrm{I}$ had Rheumatic fever. I missed quite a lot of school during that year. I battled to concentrate in class and did not find it easy to study, due to the stress.

My mother's family was very gifted. They all played a musical instrument and sang beautifully. My sister started picking out tunes on the piano from the age of 5 . She began taking music lessons from the age of 7 and had natural talent. Today she is involved in the music ministry of her church, she is a music teacher, produces musicals, runs the only musical festival (eisteddfod) in a big city, plays piano for nursery schools, and trains a school choir. Her children are also musically gifted. Only when I got to High School, did I have the opportunity to start with music lessons. Due to very bad coordination, I never excelled. In High School I joined the school choir, which I enjoyed immensely. This was one of the few things I enjoyed at school. I was never a soloist, but I have a good voice. I have always given God the glory for the fact that I have a good singing voice. I had to come to terms with the fact that I could never play a musical instrument.

For about 10 years I used to lead the singing in Sunday school, at the church where I taught Sunday school. I also produced Sunday school musical events. If we had a power failure at church, they used to turn to my mother and me to lead the singing. In 1987 I moved to Pretoria. I suffered from depression and felt much rejection; I had a nervous breakdown in 1992. I was admitted to a in a Psychiatric clinic. In counselling I was asked what the one thing was that I enjoyed in my school days and I said it was being in the school choir. The psychiatrist told me that I should join a choir. I joined the church choir at my present church in 1993. It was quite a big choir and we often did Cantata's and worked on difficult pieces, which I truly enjoyed. 
The church choir in our church also used to lead the congregational singing on a Sunday morning. Then in the year 2000 , a decision was taken to choose small worship groups who would lead the worship in the church on Sundays. These groups would be made up of choir members. So I was put in one of these worship groups.

In 2002 a new lady was appointed in charge of the worship groups, who decided that everyone should audition for the worship groups. I auditioned and was not chosen to sing in a worship group. A new woman joined our Bible study. She said she has always been involved in the music ministry. We invited her to come and join the choir. She didn't come forward and when I looked again she happened to be in Worship Group. Of course this hurt me very much.

In about the middle of 2002 I was in hospital for surgery and the associate pastor came to visit me. He then told me that a decision had been taken that our choir, known as "New Song", which by this time was only a handful of people, would become one of the ministry groups, which meant that we would lead Worship once a month. I was grateful to God for this. I used to sing without a microphone and people told me that they could hear my voice in spite of the fact that I didn't have a microphone. The worship groups were becoming very small and I volunteered my services for a second worship group. They were pleased to have me because by now they didn't have many people for the worship groups. I was a part of this group for about 18 months.

In the meantime a big group got together for three musicals. These were wonderful times of fellowship. I so looked forward to these times. I did not have a major part, but I was part of the group and my voice always came out very strongly.

At the beginning of 2004, the structure of the church changed, so the structure of the Music ministry also had to change. I have been secretary of the music Ministry for the last four years. Seven worship leaders were chosen, and they were allowed to choose their own worship team. One of my closest friends, one of the organists, was not chosen by any of the worship leaders, and I was not chosen either. We were not the only two people who were not chosen. I felt very hurt. The person in charge of the vocalists was somebody I regarded as a friend; she also trained the choir, called "New Song" and produced the musicals I had been part of. The reason why it hurt me so much is because "New Song" and the musicals had come to an end.

During the whole of 2004, I only sang in a group item during Easter. It just felt as if I had lost my usefulness as far as the ministry was concerned. This was very difficult, as singing has always been a very vital part of my life. What hurt me even more was that my friend had been left out as organist. She was hurting very much. A lot of people were unaware that she was hurting; they thought she had withdrawn due to the fact that her husband had terminal cancer.

The music director was the associate pastor and we had always had a good relationship. Yet I found that I could not talk to him about it, as his wife is a very good friend of mine and I didn't want anything to come in the way of our friendship, my relationship with him had become very strained. One day I had a call from the woman in charge of the vocalists. She said the music director had received an e-mail from a Deacon, enquiring about the fact that I was no longer in worship groups. She asked why I had never spoken to her about it and I told her just how hurt I was at this stage, due to the rejection I felt. She said I must please come to her if I have a problem, and not talk to other people about this, she said I did not have a voice to lead worship, but 
more of a choral voice. What the difference is, I'm not sure. My sister, who trains a choir of 75 girls and has been playing the piano for the Durban Chamber Choir, says there is no difference and another friend who also trains choirs said exactly the same. I never told this deacon about what happened. He acted on his own after enquiring about my absence in the worship groups.

After I had put the phone down, I thought to myself that I knew that all the talking in the world was not going to help at all, as they had made their minds up that I was not good enough. All the blame cannot be put on the worship leaders, as they also need guidance from the music director and the woman in charge of the vocalists.

What was happening to me emotionally was that all the rejection I had experienced from childhood came flooding back to me and it intensified my pain. I have been for intense counselling over the last 12 years and have worked through most of my baggage, but one just needs an incident like this to set you back.

The following month I had a phone call from the deacon involved. He had taken the matter up at the deacon's meeting. He said he had spoken about the situation and it was discussed at great length. A decision was made to reinstate everyone who had been left out of the music ministry.

The music director contacted me and said we need to get together for a meeting. We arranged a meeting for a Sunday evening after church. We chatted about it and he wanted to know what was going on. I told him that I had not spoken to the deacon at all. My experience of this deacon is that he is a man of integrity and very humble and that I am convinced that he was convicted by the Lord to bring this matter up. I was questioned over and over about this that I eventually felt as if he thought there was something going on between the deacon and me. He then apologized and said he takes all the blame and is prepared to put me into his worship team. We agreed to this.

I went home, but was very puzzled about it all. I felt as if he was just doing this to soft soap me and please the deacon concerned. I thought the matter was now resolved, but the following week I had a phone call from the woman in charge of the vocalists to say that she and the music director and I should have a meeting together. We got together one afternoon. At the time I was also doing a Counselling course, which was helping me a great deal. In this group I learnt that I could be honest about how I felt about my situation. After a long discussion, they said they had had a meeting with the senior pastor, who said he did not say that everybody had to be reinstated, but that they had to deal with the situation. This woman again said I had a Choral voice and not a voice to lead Worship and that they had decided that I would not be reinstated into any worship group. I told them that coming from a musical family, having been involved in leading singing in Sunday school, it was very difficult to come to terms with the fact that I was not good enough to be in worship groups. I told them that I always had the satisfaction of knowing that I had a good voice. My sister, who is very gifted, had always encouraged me. By the end of the meeting, they wanted to know if I was prepared to do an audition again. I decided that I would rather back down and focus on another ministry.

Although I had made the final decision, it was very difficult for me and I felt rejected. I still shed a lot of tears about the matter.

In January 2005 I had a chat to my sister about this. She was shocked. As a professional musician, her standard is high, but she says when it comes to the music 
ministry in the church, she feels different. She explained that if somebody loves the Lord and has a voice that can keep the tune, she is willing to take that person into her worship group. I think I have dealt with the way I was treated. I also know that the Lord has led me into other ministries. I know that he is in control.

\section{CASE STUDY 5}

My mother always tells me that I was a very happy little girl between the ages of one and six years old. She used to look for me only to discover that I had gone out the gate to visit the neighbours, who all loved me to bits. I was not afraid of men at all in those days.

By the time I got to school, I had become more afraid of people, due to the fact that I was very close to my mother and now had to leave my comfort zone. I had to live in my sister's shadow, as every teacher could not believe that we were sisters. She excelled at everything she did. Fortunately, it did not affect my relationship with my sister at all.

When I was 9 we moved to a new town. My father was a founding member of the church we attended and was also an elder. One of his fellow elders and his wife became good friends of our family. One day my aunt took us to visit them. My father was not with us; it was just my aunt, mother, sister and I who were there. My mother sent me to fetch something from the car. As I came running up the stairs, our host appeared. He exposed himself to me sexually and made me do something, which was a terrifying experience for me. I ran back up into the flat. My sister noticed that there was something wrong. After we had had lunch, she told my mother that there is something radically wrong with me.

We eventually went back to my aunt's house. I was very naive and did not even know that sex existed. It took my mother and my aunt ages to get an explanation out of me. My mother contacted the minister and this man. The matter was dealt with, he had to resign as an elder, but the subject was closed to me. I don't think my mother realised that I would remember every detail for the rest of my life.

I had grown up with 3 cousins who were a few years younger than me, but as from that day I was petrified of anything that was male. I had a dreadful fear of authority figures. I stayed close to these cousins and the only men I trusted were my father and one uncle.

For 20 years I never spoke to anybody about what had happened to me as a child. It was after all these years that I spoke to a good friend of mine and she spoke to the minister and then I went to see him and was able to talk about it to him, this was very difficult for me. I am now 50 and I have never even been out on a date and had to work hard to come to terms with the fact that I would never get married and have children.

I battled to cope in my work situation, as I could never talk to any of my bosses. I could not stand up for myself and was often humiliated and the chances of promotion were very slight.

It still plagued me for many years. About 12 years ago I started going for intense counselling. I then went to speak to a counsellor who dealt with Inner Healing. She said that even though it wasn't molestation, it is as bad as molestation, as you go through the same emotions. It made me grow up with the thought pattern 
that sex was dirty. She gave me a book to read and after much counselling I realised that God expected me forgive this man, who had died many years ago. This exercise was very difficult.

A couple of years later I had a nervous breakdown and started seeing a psychologist. He really helped me to deal with this. It remains at the back of my mind, and at times still gets to me.

Today, I am able to cope; I have a wonderful boss of whom I am not afraid at all. I can at least talk to men without being afraid of them. 